\title{
Slow restoration of soil microbial functions in an Acacia plantation established on degraded land in Thailand
}

\author{
R. Doi $\cdot$ S. L. Ranamukhaarachchi
}

Received: 5 March 2012 / Revised: 2 October 2012 / Accepted: 22 October 2012 / Published online: 22 February 2013

(C) Islamic Azad University (IAU) 2013

\begin{abstract}
Deforestation diminishes the ecological services that a forest provides (e.g., flood prevention). To restore such services, reforestation is often utilized. The full restoration of the original forest ecosystem, however, can take several decades. The present study was conducted to identify the missing key components for rehabilitation of a degraded plot of land in Thailand on which Acacia trees were planted 18 or 19 years ago. Canopy spectral and soil physicochemical profiles of the Acacia plantation plot showed more advanced rehabilitation than in the soil microbial functions, as represented by soil dehydrogenase activity and community-level physiological profiles, when compared with those of a natural evergreen forest. The slower restoration of the soil microbial functions was thought to: (1) be attributed to the loss of certain microbes that played important roles in the evergreen forest soil, and (2) restrict the restoration of the entire forest ecosystem which was found to be still progressing towards a full restoration of the land's original conditions. Finally, possible measures for further rehabilitation of the ecosystem were discussed.
\end{abstract}

Keywords Acacia auriculiformis - Components for ecological restoration - Land degradation and rehabilitation $\cdot$ Multivariate analysis

\footnotetext{
R. Doi $(\square)$

Graduate School of Agricultural and Life Sciences,

The University of Tokyo, 1-1-1 Yayoi, Bunkyo-ku,

Tokyo 113-8657, Japan

e-mail: roird2000@yahoo.com

S. L. Ranamukhaarachchi

School of Environment, Resources and Development,

Asian Institute of Technology,

Pathumthani 12120, Thailand
}

\section{Introduction}

Deforestation has emerged as a challenge to the socioeconomic development of Thailand (Anon 2011) and many other countries. It has been estimated that, in the past four decades alone, the forested areas in Thailand have declined by $50 \%$ or more (Fisher and Hirsch 2008). In the tropics, deforestation often leads to land degradation which, in turn, results in degraded soils (Eden and Parry 1996). Deforestation is seen as a major cause of increasingly severe problems associated with drought and flooding (Krairapanond and Atkinson 1998). Since the late 1980s, the Thai government has taken measures to rehabilitate these degraded lands. Reforestation is one of the measures employed, and trees have been planted on the degraded lands under a government-subsidized program (Sharp and Nakagoshi 2006). Because the native tree species often do not survive under the degraded soil conditions, exotic tree species are often introduced as substitutes (Ashton et al. 2001). Though the strategy is often criticized, these exotic tree species have shown rehabilitative effects in places where native species have failed (Lugo 1997).

Acacia auriculiformis is one of the introduced exotic tree species capable of surviving in the degraded lands found in the Thai savanna (Badejo 1998). Besides its high adaptability in degraded savanna areas (Badejo 1998), A. auriculiformis is known for its nitrogen-fixation property (Sprent and Parsons 2000), macrofaunal composition enrichment (Mboukou-Kimbatsa et al. 1998), low allelopathic effects (Bernhard-Reversat 1999), and ability to pump nutrients from the subsoil (Kang 1993). In Sakaerat, Thailand, A. auriculiformis was planted in a degraded part, producing evidence of the rehabilitative effects of reforestation through soil physicochemical (Doi and Ranamukhaarachchi 2007) and biotic changes (Doi and Ranamukhaarachchi 
2009a) and through changes in plant species community structure (Kamo et al. 2002). As succession progresses following the plantation of exotic tree species, native tree species may return. The restoration in Sakaerat, however, was found to be incomplete even 19 years after the trees were first introduced. In a strict sense, the Acacia plantation plots were still considered to be progressing towards full restoration to an evergreen forest. It was hypothesized that the restoration of these plots was being inhibited by the absence of key components required for full restoration (Hobbs and Norton 1996).

Given this, certain ecological aspects were considered potential components for further forest ecosystem rehabilitation and were compared in terms of the progress of the restoration taking place in Sakaerat, Thailand. This study examined whether there were differences in the degree of restoration owing to these components of ecological restoration by planting A. auriculiformis trees on degraded land under savanna climatic conditions. Above and belowground components of ecological restoration are often dependent on each other (Kardol and Wardle 2010). Further, in ecological restoration, either the above or the belowground components themselves may also exist in dependent relationships. Therefore, the canopy's spectral profile, the soil physicochemical characteristics, and the functions and the structure of the soil microbial community of the Acacia plantation plot were compared with those of the dry evergreen forest, which was the original vegetation type of the study site.

\section{Materials and methods}

\section{Site description}

This study was conducted at the Sakaerat Environmental Research Station, Thailand. The details were described elsewhere (Doi and Sakurai 2004; Doi and Ranamukhaarachchi 2007). The annual precipitation is $1,260 \mathrm{~mm}$ and the average temperature is $26{ }^{\circ} \mathrm{C}$. The climate is classified as savanna (Köppen 1931). The soil is originally an Orthic Acrisol, according to the FAO/UNESCO classification system (FAO/UNESCO 1979). We compared soils of dry evergreen forest (the original vegetation), Acacia plantation, and bare ground (the most degraded state of vegetation). These vegetation types represent a land degradationrehabilitation gradient. The vegetation types were randomly distributed. Thus, the vegetation mosaic was regarded as a completely randomized design (Fig. 1). The numbers of replications were 2, 4 and 2 for dry evergreen forest, Acacia plantation and bare ground, respectively. All the sampling points were taken on slight slopes (less than $10^{\circ}$ ).
The dry evergreen forest is primarily dominated by Hopea ferrea and Shorea spp. that form the upper storey, $20-40 \mathrm{~m}$ above ground level. A typical dry evergreen forest contains more than 1,000 trees (trunk diameter at breast height $>5 \mathrm{~cm}$ ) $\mathrm{ha}^{-1}$, the total basal area at a height of $1.3 \mathrm{~m}$ exceeds $30 \mathrm{~m}^{2} \mathrm{ha}^{-1}$, and the aboveground biomass is over 200 tons ha ${ }^{-1}$ (Kanzaki et al. 1995).

The A. auriculiformis plantation plots are scattered throughout the area (Fig. 1). The Acacia plantation plots were established in 1986 and 1987 in areas that had previously been subjected to slash-and-burn shifting cultivation (Kaeoniam et al. 1976). In these areas, the original vegetation had been removed and the aboveground biomass had been burned. The cleared land had been cultivated for a few years, and then abandoned when the soil quality deteriorated to the point where it could no longer support crop production. Some of the abandoned portions of Sakaerat had been converted to plantation plots of Acacia mangium, Eucalyptus camaldulensis and other tree species. A. auriculiformis was one of the introduced tree species.

Bare ground can still be seen at some points in Sakaerat. The bare ground sampling points had been intensively deprived of soil nutrients and had lost conditions seen in the forest soils (Doi and Sakurai 2004). At these sampling points, recovery of vegetative cover did not occur since the harsh conditions make it too difficult for plants to survive. The uppermost horizon is reddish brown, rich in gravel, and has few roots and other plant organs/debris. The true color remote sensing image was previously reported (Doi and Ranamukhaarachchi 2010).

Spectral profiling of soil sampling points in remote sensing image

In this study, a true color remote sensing image provided by Google Earth was used. The remote sensing image was captured by the satellite Quickbird on 3 April 2006. A virtual altitude of $1,000 \mathrm{~m}$ above ground level was chosen when copying the remote sensing image from the Google Earth window using the "copy image" function. The original multispectral image included data on red-green-blue color intensity and panchromatic grayscale values. When the image was copied from the Google Earth window, the data regarding the values of the red-green-blue color intensity were retained. The image was used for the multivariate color profiling of the canopy or bare ground using Adobe Photoshop 7.0 as previously described (Doi 2012; Doi et al. 2010). The intensity values of red, green, blue, cyan, magenta, yellow and $L^{*}$ and the values of $a^{*}$ and $b^{*}$ were read. 
Fig. 1 Map of the research area in Sakaerat, Thailand. Brightness and contrast were increased from the original values for clarification

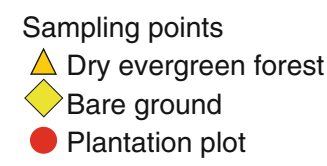

Sampling points

$\triangle$ Bare ground

Plantation plot

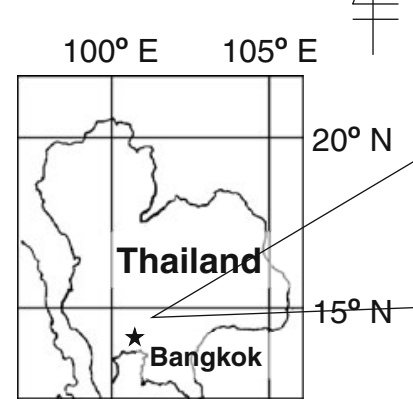

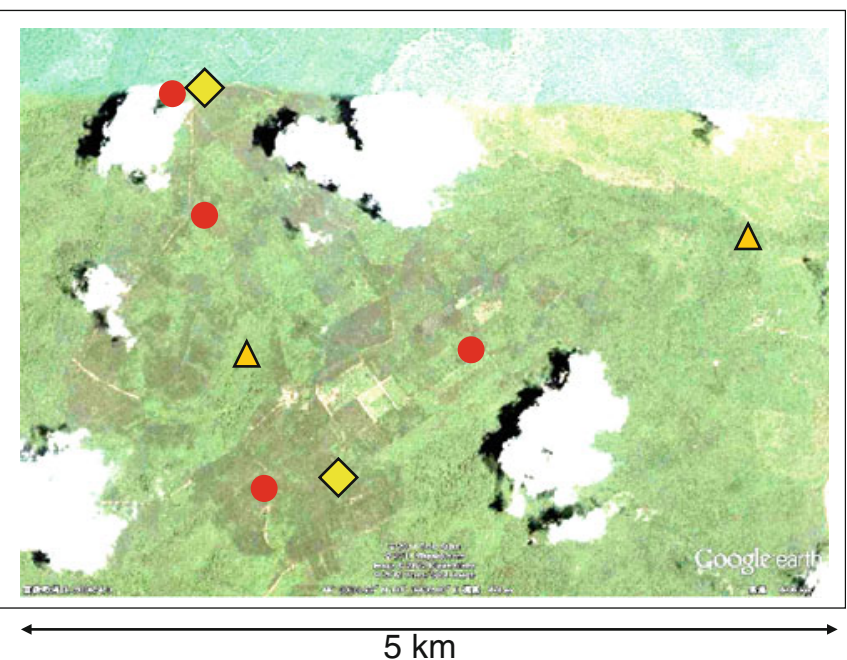

$5 \mathrm{~km}$
Soil sampling and physicochemical profiling

Soils were sampled on 24 and 25 December 2005. The sampling was performed within a 26-h period, during which the site experienced negligible precipitation $(<1 \mathrm{~mm})$. At each sampling point, $100-\mathrm{mL}$ core samplers, $5 \mathrm{~cm}$ in diameter, were inserted from the surface to a depth of $5.1 \mathrm{~cm}$. A circle, $10 \mathrm{~m}$ in diameter was established, and eight soil cores were randomly taken from within the circle. In addition, two other cores were randomly taken from within the circle for soil moisture and bulk density measurements. The eight soil cores were immediately placed into a single plastic bag, mixed, and brought to the laboratory. For soil dehydrogenase activity measurement and community-level physiological profiling, described later, the moist soil was immediately passed through a $2-\mathrm{mm}$ sieve and then transported to the laboratory and analyzed within $12 \mathrm{~h}$. For other soil profiling purposes, the soil samples were air-dried, passed through a $2-\mathrm{mm}$ sieve, and then analyzed. Physicochemical profiling of soils was performed as previously described (Doi and Ranamukhaarachchi 2007).

Dehydrogenase activity measurement and communitylevel physiological profiling

Soil dehydrogenase activity was determined as described by Casida et al. (1964) via colorimetric measurement of the reduction of 2,3,5-triphenyltetrazolium chloride to triphenyltetrazolium formazan. The details of this process are previously described (Doi and Ranamukhaarachchi 2009b).

The bacterial community in each composite sample was profiled with community-level physiological profiling using three Biolog EcoPlates with 31 carbon sources as previously described (Doi and Ranamukhaarachchi 2009a). Five grams of each soil sample were suspended in $45 \mathrm{~mL}$ of sterilized $0.85 \%(\mathrm{w} / \mathrm{v}) \mathrm{NaCl}$ and reciprocally shaken at room temperature for $30 \mathrm{~min}$ at $120 \mathrm{rpm}$. The suspension was centrifuged at $1,000 \mathrm{~g}$ for $5 \mathrm{~min}$, decanted, and the pellet was re-suspended in $45 \mathrm{~mL}$ of the $\mathrm{NaCl}$ solution. Centrifugation and suspension were then repeated twice. The soil suspension was left still for $1 \mathrm{~min}$, and $10 \mathrm{~mL}$ of the uppermost section was diluted 40 -fold with the $\mathrm{NaCl}$ solution. This suspension was used to inoculate a Biolog EcoPlate at a rate of $0.1 \mathrm{~mL} /$ well. Oxidation of each carbon source was measured by quantifying purple color development as a result of the reduction of tetrazolium violet. The plates were incubated in the dark at $26^{\circ} \mathrm{C}$, and absorbance at $405 \mathrm{~nm}$ was read using a microplate reader (Perlong DNM-9602G, Nanjing, PR China) at 4- to 12-h intervals for 7 days. During the incubation, the plates were wrapped in a plastic film to avoid desiccation. Values for the three above-mentioned pseudo-replicates were averaged, and then used for statistical analyses.

\section{Profiling structure of soil bacterial community}

A polymerase chain reaction-denaturing gradient gel electrophoresis (DGGE) method was used to analyze bacterial community structures of the soils. Soil DNA was extracted using a commercial kit (Power Soil ${ }^{\mathrm{TM}}$ DNA Isolation Kit, Mo-BIO Laboratories, Inc., Carlsbad, CA, USA) according to the manufacturer's instructions. The V3 region of the $16 \mathrm{~S}$ ribosomal RNA gene of the soil bacterial community was amplified using universal primers GC341F (341F with a GC clamp) and 907R (Ponnusamy et al. 2011) using a Takara Ex Taq ${ }^{\mathrm{TM}}$ polymerase kit (Takara Bio Inc., Otsu, Japan). A DNA quantity of between 0.7 and $2.1 \mathrm{ng}$ was used as the template DNA. In amplification of the V3 region, a polymerase chain reaction was initiated by denaturing the sample at $95{ }^{\circ} \mathrm{C}$ for $5 \mathrm{~min}$, followed by $\times 19$ polymerase chain reaction cycles $\left[95^{\circ} \mathrm{C}\right.$ for $1 \mathrm{~min}, 62{ }^{\circ} \mathrm{C}$ 
$\left(-0.8{ }^{\circ} \mathrm{C}\right.$ per cycle) for $1 \mathrm{~min}$, and $72{ }^{\circ} \mathrm{C}$ for $\left.1 \mathrm{~min}\right]$. These cycles were followed by 9 cycles of $95{ }^{\circ} \mathrm{C}$ for $1 \mathrm{~min}, 52{ }^{\circ} \mathrm{C}$ for $1 \mathrm{~min}$, and $72{ }^{\circ} \mathrm{C}$ for $1 \mathrm{~min}$, then the final elongation at $72{ }^{\circ} \mathrm{C}$ for $10 \mathrm{~min}$. The amplified DNA was separated by DGGE with 20-60\% urea-formamide denaturing gradients $(100 \%$ denaturant was defined as $7 \mathrm{M}$ urea and $40 \%$ formamide). The gel contained $6 \%$ polyacrylamide in $\times 0.5$ strength Tris-acetate-ethylenediaminetetraacetic acid buffer $(20 \mathrm{mM}$ Tris, $10 \mathrm{mM}$ acetic acid, and $0.5 \mathrm{mM}$ ethylenediaminetetraacetic acid, $\mathrm{pH}$ 8.4. The gel was stained with SYBR Gold (Invitrogen, Carlsbad, CA, USA) and photographed with a blue LED transilluminator (OptCode, Corp., Tokyo, Japan). Band intensities were determined using the analytical software Gel Analyzer (Istvan Lazer). The most significant bands as indicators of land degradation or rehabilitation/conservation were selected by performing a principal component analysis described later. The most significant indicator bands were recovered from the gel, amplified as above in 20 cycles of polymerase chain reaction $\left(95{ }^{\circ} \mathrm{C}\right.$ for $1 \mathrm{~min}, 54{ }^{\circ} \mathrm{C}$ for $1 \mathrm{~min}$, and $72{ }^{\circ} \mathrm{C}$ for $1 \mathrm{~min}$ ) followed by a final elongation at $72{ }^{\circ} \mathrm{C}$ for $10 \mathrm{~min}$. The amplified DNA fragment was cyclesequenced using Big-Dye ${ }^{\mathrm{TM}}$ Terminator Ver 3.0 (Applied Biosystems, Inc., Foster City, CA, USA), then sequenced by running a PRISM ${ }^{\mathrm{TM}}$ 3100-Avant Genetic Analyzer (Applied Biosystems, Inc.). The closest relative of the bacterium represented by the DGGE band was retrieved from the Genbank database, BLAST (National Center of Biotechnology Information).

\section{Data analyses}

The following analyses were performed using the statistical software SPSS 10.0.1 (SPSS Inc., Chicago, IL, USA). Analysis of variance for each of the soil and canopy variables was performed. Community-level physiological profiles of the soils were analyzed to construct qualitatively different data sets (Doi and Ranamukhaarachchi 2009a) by applying the kinetic approach proposed by Lindstrom et al. (1998). Continuously measuring the intensity of the purple color development, a value of absorbance known as asymptote (K) was determined statistically for each of the 31 carbon sources. As absorbance value increased with incubation time, the value of asymptote $\mathrm{K}$ was determined to be the point at which the absorbance value essentially converged at $405 \mathrm{~nm}$. The $0.95 \mathrm{~K}$ time point was regarded as the convergence stage (Lindstrom et al. 1998). This approach thus provided a $0.95 \mathrm{~K}$ data set consisting of multivariate profiles of the soils. In addition, another technique for constructing an area data set was applied. In this technique, a soil's multivariate profile was determined by integrating the area [absorbance $\times$ incubation time $(h)$ ] under the color development curve by reading the absorbance value at $405 \mathrm{~nm}$ (Hackett and Griffiths 1997) for each of the 31 carbon sources. Thus the area data set was constructed by gathering all the soils' area profiles. Then, a ratio-transformation was performed, i.e., each observed value was divided by the sum of all the 31 observed values for the soil sample and used for statistical analyses. The same ratio-transformation was also employed to obtain a DGGE profile of the soil by dividing each value of band intensity by the sum of all the values of band intensity for the soil sample.

Principal component analysis was performed to extract principal components from the data set on the remote sensing, soil physicochemical, or soil bacterial profiles. The community-level physiological and the DGGE profiles were used as soil bacterial profiles.

Wilk's lambda statistic was determined to quantify the discriminatory power of the profiling methods to discriminate among the groups which consisted of the evergreen forest, the Acacia plantation plot, and the bare ground groups. If the mean values among compared groups for each variable are equal, Wilk's lambda becomes 1 . Conversely, as the difference between multivariate profiles increases, Wilk's lambda moves closer to 0 . Thus a small Wilk's lambda value indicates the high discriminatory power of the profiling method (Zar 1999).

\section{Results and discussion}

Figure 2 shows spectral profiles of the forest canopies and the bare ground. Vegetation type was a significant $(p<0.05)$ source of variation in the color components, except for magenta. The land degradation-rehabilitation gradient is shown as the relationships in which the bare ground was clearly separated from the forest canopies. Between the forest canopies, relatively clearer differences were suggested by yellow and $b^{*}$. The similarity in the spectral profile between the Acacia plantation plot and the evergreen forest shows that 18 or 19 years after the Acacia plantation, the plantation plots had largely restored the original ecosystem.

Figure 3 presents physicochemical profiles of the soils. Vegetation type was a significant source of variation in moisture, $\mathrm{pH}$, organic matter, exchangeable $\mathrm{K}^{+}$, and soil fertility index $(p<0.05)$. The land degradation-rehabilitation gradient is shown as the relationship in which the bare ground soil was separated from the forest soils according to the soil fertility index, which was the comprehensive indicator of soil fertility. Land degradation was described by dryness, heaviness, poor organic matter content, low value of soil fertility index, high acidity, and the deteriorated soil buffering function indicated by small values of cation exchange capacity. According to Fig. 3, 
Fig. 2 Multispectral profiles of the bare ground filled diamond), the Acacia plantation plots (open circle), and the evergreen forest (filled triangle) based on the remote sensing image acquired in April 2006

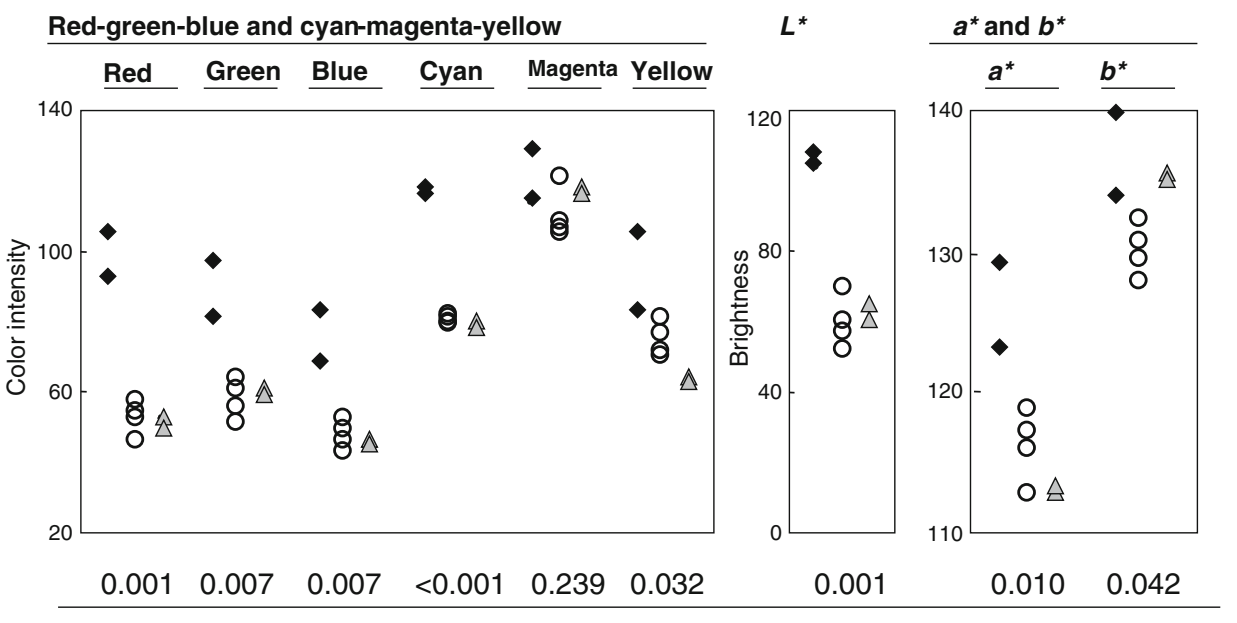

$p$ vaules provided by analyses of variance hypothesizing vegetation type as the source of variation the Acacia plantation soil had largely restored the original physicochemical conditions.

These results indicate the completeness of the above components for ecosystem restoration (Figs. 2, 3). However, soil bacterial functions highlighted differences among the three vegetation types as indicated by small $p$ values $(<0.006)$ provided by the analyses of variance (Fig. 4$)$. The bare ground soil was the poorest, and the evergreen forest soil the most functional. The soil of the Acacia plantation plot tended to lie between these two extremes. According to Fig. 4, the Acacia plantation soil was still progressing towards full restoration to evergreen forest soil.

To present bacterial community structures of the soils, DGGE profiles of the soils are shown in Fig. 5. The use of gel analyzer eventually detected 40 bands, and the band intensities were ratio-transformed as mentioned above.
This transformation provided DGGE profiles of the soils which were used for principal component analysis.

The remote sensing profiles of the forests and the bare ground were most clearly discriminated in the principal component score plot as shown by the smallest $p$ value of 0.045 and a Wilk's lambda value of smaller than 0.001 (Fig. 6). The $0.95 \mathrm{~K}$ data set was the second clearest in terms of discrimination of the soils, as indicated by small lambda $(<0.001)$ and $p(0.093)$ values. The area data set, as another community-level physiological data set, and the soil physicochemical data set were comparable in terms of clarity of discrimination of the soil sample groups, while the DGGE data set was the poorest in discriminatory power among the five data sets.

The single remote sensing and the soil physicochemical variables as indicators of the land degradation and

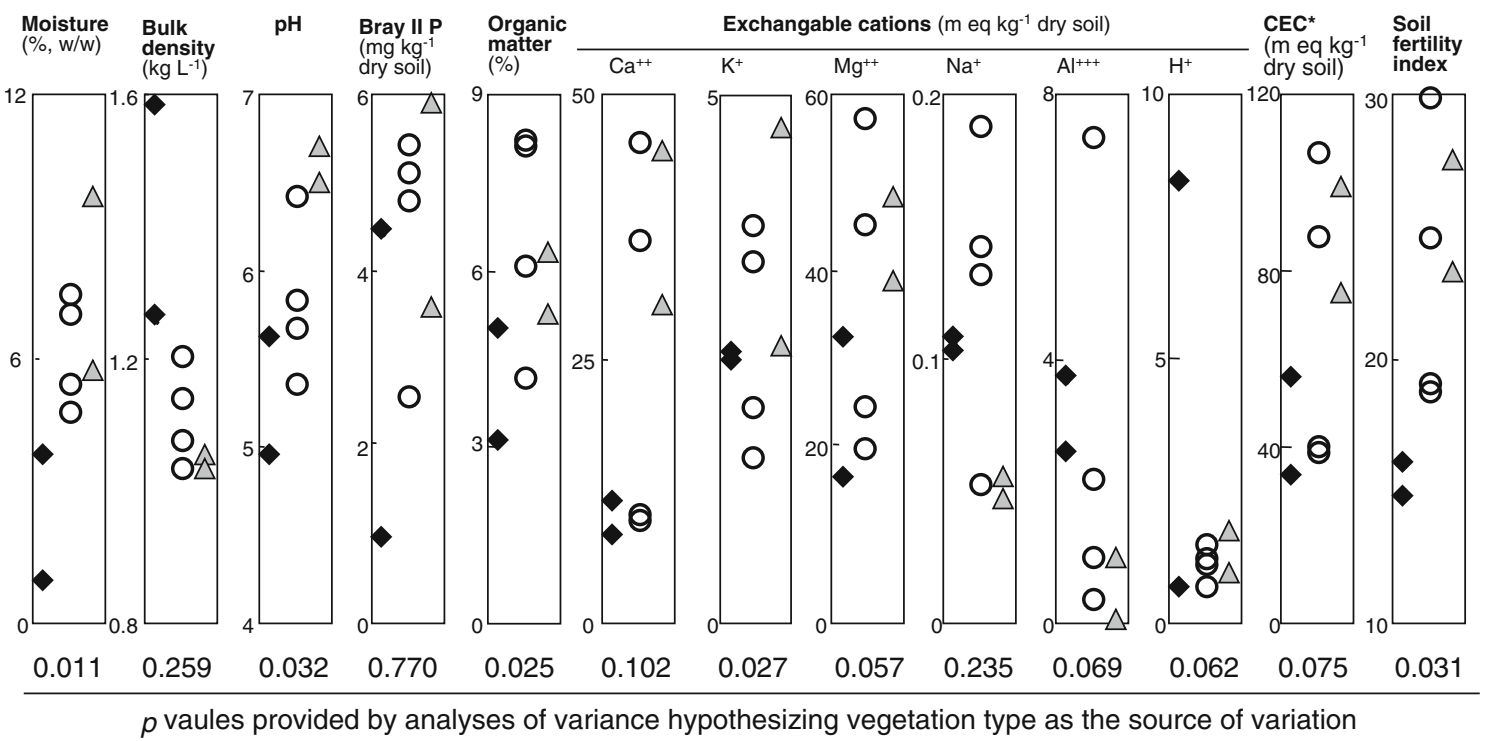

Fig. 3 Physicochemical characteristics of the soils of the bare ground (filled diamond), the Acacia plantation plots (open circle), and the evergreen forest (filled triangle). *Cation exchange capacity 
rehabilitation are summarized in Table 1. Since the first principal component for these data sets showed the degradation and rehabilitation/conservation (Doi and Sakurai 2004), the single variables with great absolute values of eigenvector are the indicators of the land degradation or rehabilitation/conservation. The eigenvectors for the remote sensing variables indicate that a large value of color intensity or brightness indicates that the bare ground was light-colored. On the other hand, according to the soil

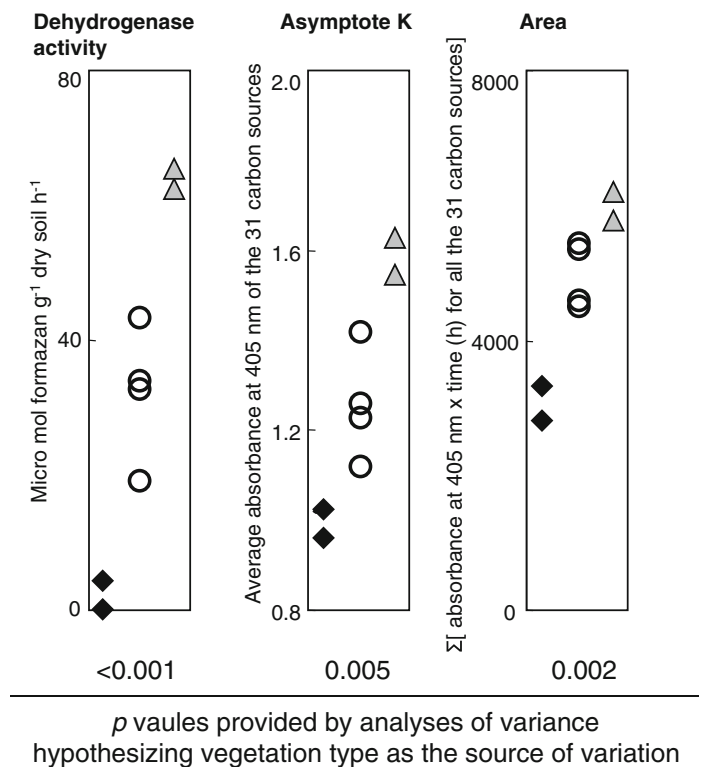

Fig. 4 Bacterial functions of the soils from the bare ground (filled diamond), the Acacia plantation plots (open circle), and the evergreen forest (filled triangle) physicochemical data, the land rehabilitation/conservation was described by high values of $\mathrm{pH}$, exchangeable cations $\left(\mathrm{Mg}^{++}, \mathrm{Ca}^{++}, \mathrm{K}^{+}\right)$, cation exchange capacity, rich organic matter content and greater soil moisture. Great exchangeable acidity $\left(\mathrm{Al}^{+++}, \mathrm{H}^{+}\right)$and bulk density of soil described the land degradation as shown in Fig. 3.

Table 2 shows that the land rehabilitation/conservation was indicated by the relatively intensive use of glycyl-Lglutamic acid, D-malic acid, $\alpha$-cyclodextrin, and $i$-erythritol by the soil bacteria, while the land degradation was indicated by the intensive use of putrescine, tween 40 , and itaconic acid by the soil bacteria.

The DGGE bands that most significantly contributed to the first principal component axis in Fig. 6 were sequenced. Band 3 could not be sequenced, possibly because of the existence of DNA fragments of multiple bacterial species in the band. Based on the ribosomal DNA sequences, the closest matching relatives were chosen from other soils (Table 3). The closest relative to the bacterium represented by the DGGE band as an indicator of the rehabilitation/conservation was an unidentified bacterium from a Ferralsol in Madagascar, and the second closest was an uncultured bacterium from the soil of a plot of 20-yearold grassland, which is part of a restoration ecosystem from a crop rotation agricultural land in subtropical China (Chen et al. 2012). The land degradation was described by the relatively high occurrence of the bacteria close to those found in disturbed soils under a coniferous monoculture in Taiwan (Lin et al. 2011), a Korean ginseng field (Baek et al. 2011), a pasture land (Jangid et al. 2008), pyreneexposed soil, or volcanic deposits.
Fig. 5 The denaturing gradient gel electrophoresis profile (band patterns) of amplified 16S ribosomal DNA from genomic DNA extracted from the soils of the bare ground, the Acacia plantation plots, and the evergreen forest. In the electrophoresis, $20 \%$ (top) to $60 \%$ (bottom) denaturing gradients were used. The orange arrows indicate the bands subsequently analyzed. *Bare, bare ground; **Evergreen, evergreen forest

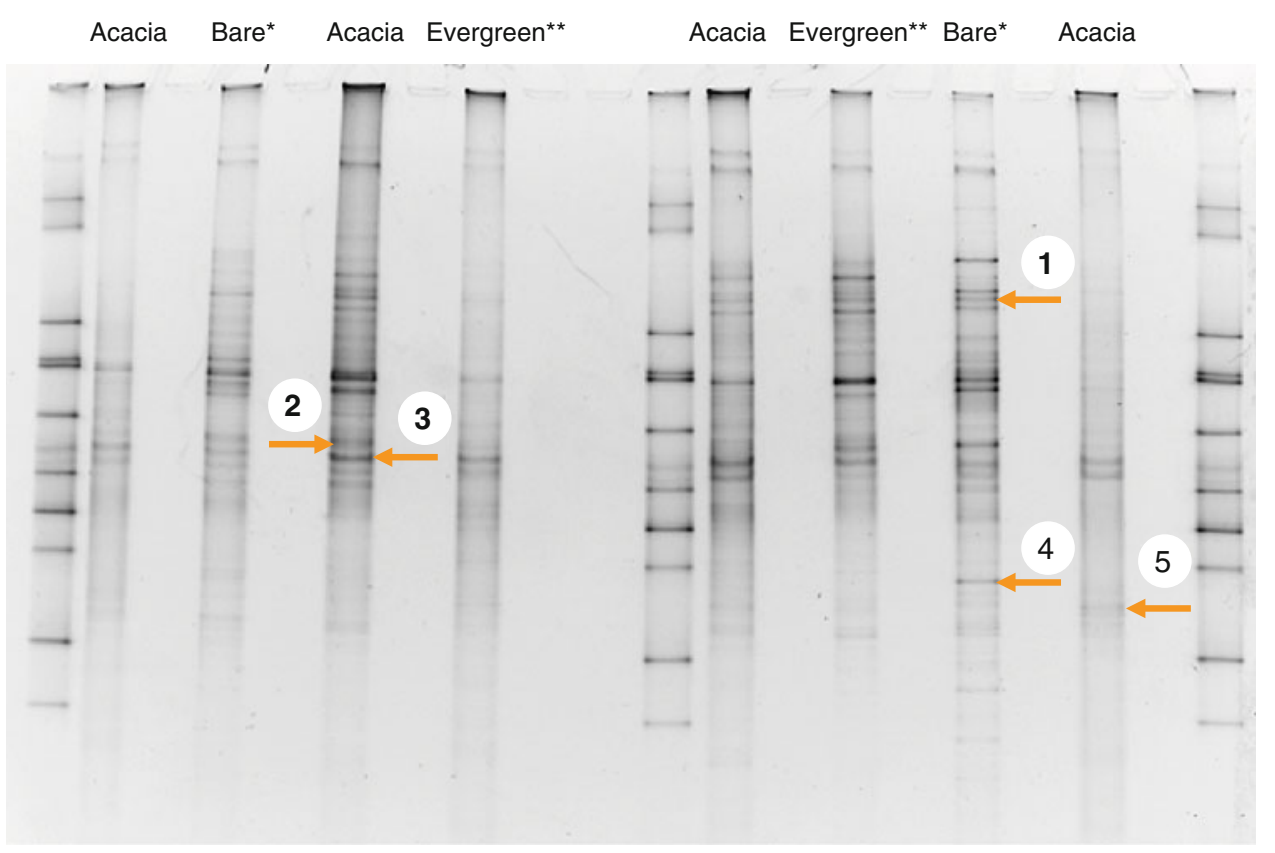


2

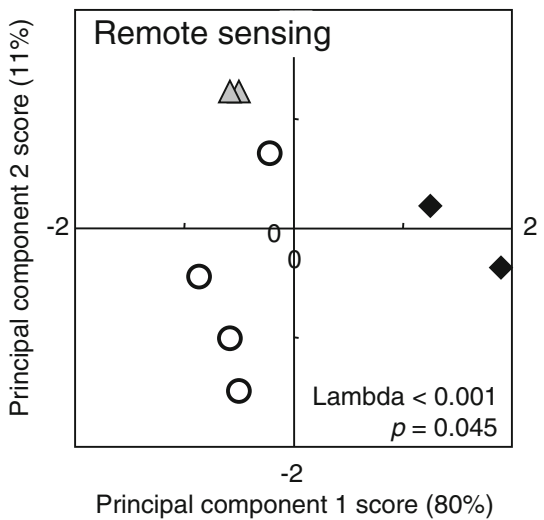

2

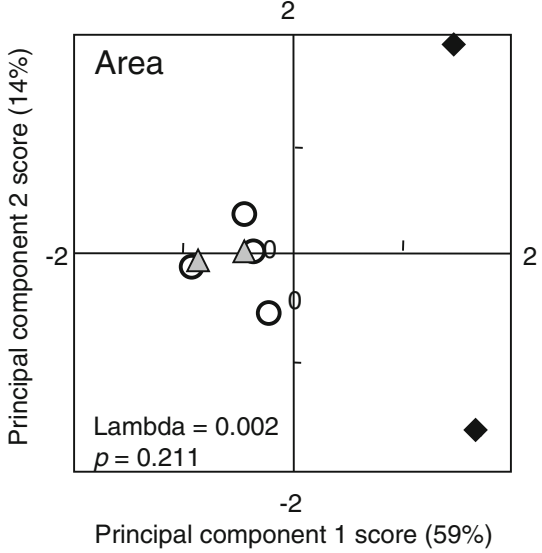

2

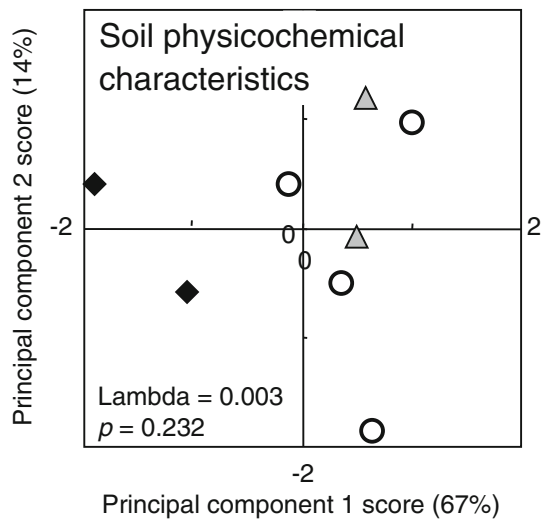

2

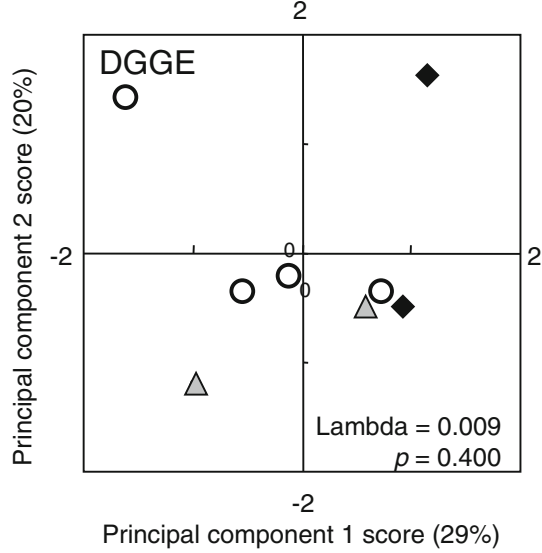

2

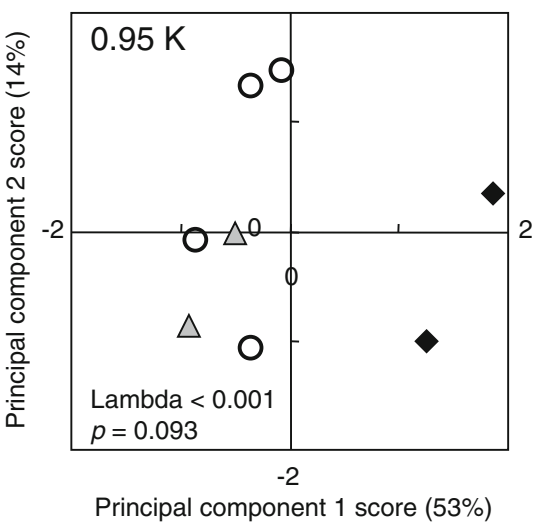

Fig. 6 Principal component score plots to show principal component scores for the bare ground (filled diamond), the Acacia plantation plots (open circle), and the evergreen forest (filled triangle) for each

Apparently, the remote sensing and soil physicochemical data sets show that the Acacia plantation had largely restored the conditions seen in the evergreen forest canopy and soil (Figs. 2, 3). The same rehabilitative trend was also shown by the principal component score plots from the data sets in which the Acacia plantation and the evergreen forest had comparable scores on the first principal components (Fig. 6). These comparisons highlight the proximity of the Acacia and the evergreen forest ecosystems (Mitchell et al. 2000). However, there was evidence of incomplete restoration of the original ecosystem as suggested by other variables. Here, the mechanisms behind this incomplete restoration and the measures for the enhancement of the rehabilitation will be discussed.

Slow restoration of soil microbial functions

The scores on the first principal component for the Acacia plantation and the evergreen forest are comparable (Fig. 1), but the values of soil dehydrogenase activity, asymptote $\mathrm{K}$, and area (Fig. 4) show a delay in the restoration of the soil microbial functions in the Acacia plantation soil compared of the aspects of the land degradation and rehabilitation due to the Acacia reforestation

to the aboveground and soil physicochemical restoration. Soil dehydrogenase activity is quantified measuring the reddish coloration generated when the tetrazolium compound accepts electrons released from the substrate as a result of the oxidation. Hence, the value of dehydrogenase activity represents activities of various dehydrogenases, which play fundamental roles in microbial activity, such as driving the citrate cycle (Vonmersi and Schinner 1991). Therefore soil dehydrogenase activity is an integrative measure of total soil microbial activities and thus could still show the difference between the Acacia plantation and the evergreen forest soils in Fig. 4, possibly by integrating subtle differences in the activities of various single dehydrogenases. The high significance $(<0.001)$ of vegetation type as a source of variation of soil dehydrogenase activity may be contributed to by soil fungi that do not oxidize the tetrazolium compound in the Biolog EcoPlate (PrestonMafham et al. 2002) which provided the values of asymptote $\mathrm{K}$ and area. Therefore, the values of asymptote $\mathrm{K}$ and area represented the integrative bacterial functions of the Acacia plantation soil moving towards full restoration to evergreen forest in terms of soil bacterial function 
Table 1 Eigenvectors for the single variables contributed to the first principal components from the remote sensing and the soil physicochemical data sets

\begin{tabular}{|c|c|c|c|c|}
\hline \multirow[t]{2}{*}{ Indication } & \multicolumn{2}{|c|}{ Remote sensing data set } & \multicolumn{2}{|c|}{$\begin{array}{l}\text { Soil physicochemical } \\
\text { data set }\end{array}$} \\
\hline & Variable & Eigenvector & Variable & Eigenvector \\
\hline \multirow{7}{*}{$\begin{array}{c}\text { Rehabilitation/ } \\
\text { conservation }\end{array}$} & \multirow[t]{7}{*}{ None } & \multirow[t]{7}{*}{-} & $\mathrm{pH}$ & 0.98 \\
\hline & & & $\mathrm{Mg}^{++}$ & 0.95 \\
\hline & & & $\mathrm{CEC}^{\mathrm{a}}$ & 0.94 \\
\hline & & & $\mathrm{Ca}^{++}$ & 0.91 \\
\hline & & & $\mathrm{K}^{+}$ & 0.91 \\
\hline & & & Moisture & 0.85 \\
\hline & & & $\begin{array}{r}\text { Organic } \\
\text { matter }\end{array}$ & 0.84 \\
\hline \multirow[t]{7}{*}{ Degradation } & Red & 1.00 & $\mathrm{Al}^{+++}$ & -0.91 \\
\hline & Luminosity & 1.00 & $\mathrm{H}^{+}$ & -0.89 \\
\hline & Green & 0.98 & $\begin{array}{l}\text { Bulk } \\
\text { density }\end{array}$ & -0.89 \\
\hline & Blue & 0.98 & & \\
\hline & $L^{*}$ & 0.98 & & \\
\hline & Cyan & 0.97 & & \\
\hline & Yellow & 0.82 & & \\
\hline
\end{tabular}

Variables with |Eigenvectorl $>0.80$ were selected

${ }^{\text {a }}$ Cation exchange capacity

Table 2 Eigenvectors for the single variables contributed to the first principal components from the community-level physiological data sets

\begin{tabular}{|c|c|c|c|c|}
\hline \multirow[t]{2}{*}{ Indication } & \multicolumn{2}{|l|}{$0.95 \mathrm{~K}$ data set } & \multicolumn{2}{|l|}{ Area data set } \\
\hline & Variable & Eigenvector & Variable & Eigenvector \\
\hline \multirow[t]{6}{*}{$\begin{array}{r}\text { Rehabilitation/ } \\
\text { conservation }\end{array}$} & $\begin{array}{l}\text { Glycyl-L- } \\
\text { glutamic } \\
\text { acid }^{\mathrm{a}}\end{array}$ & -0.90 & $\begin{array}{l}\text { Alpha- } \\
\text { cyclodextrin }\end{array}$ & -0.93 \\
\hline & D-Malic acid & -0.89 & $\begin{array}{l}\text { Glycyl-L-glutamic } \\
\text { acid }\end{array}$ & -0.93 \\
\hline & $\begin{array}{l}\text { Alpha- } \\
\text { cyclodextrin }\end{array}$ & -0.88 & $\begin{array}{l}\text { Gamma- } \\
\text { hydroxybutyric } \\
\text { acid }\end{array}$ & -0.89 \\
\hline & Glycogen & -0.82 & D-Malic acid & -0.87 \\
\hline & $i$-Erythritol & -0.81 & $\begin{array}{l}\text { 2-Hydroxy } \\
\text { benzoic acid }\end{array}$ & -0.85 \\
\hline & $\begin{array}{l}\text { D, L-Alpha- } \\
\text { glycerol } \\
\text { phosphate }\end{array}$ & -0.78 & $i$-Erythritol & -0.83 \\
\hline \multirow[t]{6}{*}{ Degradation } & Putrescine & 0.86 & A-D-lactose & 0.93 \\
\hline & D-Cellobiose & 0.90 & Itaconic acid & 0.93 \\
\hline & Tween 40 & 0.90 & $\begin{array}{l}\text { D-Galacturonic } \\
\text { acid }\end{array}$ & 0.95 \\
\hline & Itaconic acid & 0.91 & $\begin{array}{l}\text { Pyruvic acid } \\
\text { methyl ester }\end{array}$ & 0.96 \\
\hline & D-Mannitol & 0.92 & Putrescine & 0.97 \\
\hline & A-D-lactose & 0.97 & Tween 40 & 0.98 \\
\hline
\end{tabular}

Variables with |Eigenvectorl $>0.75$ were selected

${ }^{a}$ Underlined carbon sources are common between the data sets
(Fig. 4). These results reveal the incomplete restoration of the original soil microbial functions in the Acacia plantation plot.

A community-level physiological profile given as an asymptote $\mathrm{K}$ or an area profile may be strongly related to the bacterial community structure (Gamo and Shoji 1999). Therefore, the DGGE profiles were expected to discriminate among the soils, though unsuccessful discrimination was seen in Fig. 6. In Table 3, ribosomal DNA sequences from the same Ferralsol in Madagascar were the closest relatives to the ribosomal DNA sequences from the soils of the bare ground and the evergreen forest. As shown in Fig. 5, all the soils shared some of the same major bands. The existence of the soil bacteria commonly seen in the soils should have made the discrimination ambiguous (Fig. 6). In this study, DGGE profiles did not clearly discriminate between the soils, but at present, no study has been conducted to compare the discriminatory power of community-level physiological profiling and DGGE based on statistics such as Wilk's lambda. This seems to indicate that a variety of multivariate soil profiling methods are worth being examined in the evaluation of land ecosystem restoration (Ramsey et al. 2006). Another possible explanation was that the bare ground soil contained extracellular DNA fragments from the evergreen forest bacteria that could firmly attach to the bare ground soil particles because of the low $\mathrm{pH}$ and poor cation content (Trevors 1996). The remaining DNA fragments from the evergreen soil bacterial community might, therefore, be a cause of the ambiguous discrimination among the soils.

While the values of soil microbial activity shown in Fig. 4 represent the integrative redox activities of the microbial cells, they may reflect biochemical diversity in the soil (Table 2). A rhizosphere soil bacterial community showed its unique carbon source utilization profile revealed by community-level physiological profiling (Garland 1996). Changes in soil amino acid profile were recognized along a successional sequence of boreal forest (WerdinPfisterer et al. 2009). Furthermore, Fujii et al. (2010) found differences in the profile of the occurrence of low molecular compounds which consisted of monosaccharides and organic acids among soils of Japanese forests with different vegetation types. In the latter study, the low molecular organic compounds were rapidly and continuously produced and consumed. Therefore, it is possible that the evergreen forest soil has richer diversity in, and possibly faster metabolic turnover of, available low molecular organic compounds for microbes. Werdin-Pfisterer et al. (2009) concluded that the composition of soil amino acids did not significantly change across a successional sequence in Alaska, while Strobel et al. (1999) found significant differences among concentrations of aliphatic carboxylic acids in soils under different vegetation types and arable 
Table 3 Identity of 16S ribosomal DNA sequences that indicate land rehabilitation/conservation and degradation

\begin{tabular}{|c|c|c|c|c|c|c|c|c|}
\hline Indication & $\begin{array}{l}\text { Band in } \\
\text { Fig. } 5\end{array}$ & Eigenvector $^{\mathrm{a}}$ & $\begin{array}{l}\text { Closest relative } \\
\text { from soils }\end{array}$ & $\begin{array}{l}\text { BLAST } \\
\text { accession number }\end{array}$ & $\begin{array}{l}\text { Soil sample's } \\
\text { origin }\end{array}$ & $\begin{array}{l}\text { Similarity } \\
(\%)^{\mathrm{b}}\end{array}$ & $\begin{array}{l}\text { Total } \\
\text { score }^{c}\end{array}$ & Reference \\
\hline \multirow[t]{2}{*}{$\begin{array}{c}\text { Rehabilitation/ } \\
\text { conservation }\end{array}$} & 5 & -0.510 & $\begin{array}{l}\text { Unidentified } \\
\text { bacterium }\end{array}$ & FQ732438 & Ferralsol & 99.2 & 641 & Unpublished \\
\hline & & & $\begin{array}{r}\text { Uncultured } \\
\text { bacterium }\end{array}$ & EU881212 & $\begin{array}{l}\text { Natural } \\
\text { restoration } \\
\text { site }\end{array}$ & 95.7 & 813 & $\begin{array}{l}\text { Chen et al. } \\
\text { (2012) }\end{array}$ \\
\hline \multirow[t]{7}{*}{ Degradation } & 1 & 0.764 & $\begin{array}{c}\text { Unidentified } \\
\text { bacterium }\end{array}$ & FQ703663 & Ferralsol & 97.9 & 850 & Unpublished \\
\hline & & & $\begin{array}{l}\text { Uncultured } \\
\text { Firmicutes }\end{array}$ & GU016126 & $\begin{array}{l}\text { Monoculture } \\
\text { forest }\end{array}$ & 97.9 & 846 & $\begin{array}{l}\text { Lin et al. } \\
\text { (2011) }\end{array}$ \\
\hline & 2 & 0.766 & $\begin{array}{l}\text { Tumebacillus } \\
\text { ginsengisoli }\end{array}$ & AB245375 & Ginseng field & 99.1 & 946 & $\begin{array}{l}\text { Baek et al. } \\
\quad(2011)\end{array}$ \\
\hline & & & $\begin{array}{r}\text { Uncultured } \\
\text { bacterium }\end{array}$ & FR687484 & $\begin{array}{l}\text { Pyrene- } \\
\text { degrading } \\
\text { soil }\end{array}$ & 98.9 & 941 & Unpublished \\
\hline & & & $\begin{array}{l}\text { Uncultured } \\
\text { Bacilli }\end{array}$ & EF075265 & Pasture land & 98.5 & 929 & $\begin{array}{l}\text { Jangid et al. } \\
\text { (2008) }\end{array}$ \\
\hline & 4 & 0.513 & $\begin{array}{r}\text { Uncultured } \\
\text { bacterium }\end{array}$ & JN093291 & $\begin{array}{l}\text { Vetiveria } \\
\text { rhizosphere }\end{array}$ & 100 & 726 & Unpublished \\
\hline & & & $\begin{array}{l}\text { Micrococcaceae } \\
\text { bacterium }\end{array}$ & DQ490463 & $\begin{array}{l}\text { Volcanic } \\
\text { deposits }\end{array}$ & 99.0 & 702 & Unpublished \\
\hline
\end{tabular}

a The most significant single bands (IEigenvectorl $>0.5$ ) were selected. Band 3 in Fig. 5 could not be sequenced

b The first and second best matching relatives, or those with similarity $>98 \%$, were selected

c The length coverage (number of bases) of the sequenced DNA fragment

lands. If the Acacia plantation soil has a simpler profile of microbiologically available organic compounds than does the evergreen forest remains to be investigated in the future.

\section{Diversity of vegetation}

If the relative microbial inactiveness of the Acacia plantation soil compared with the evergreen forest soil is due to a simpler composition of the tree community resulting in the availability of a simpler composition of microbiologically available soil organic compounds, then the spectral profile of the canopy may also be simple and thus would have a smaller value of coefficient of variation of the canopy spectral variable expressed as:

Coefficient of variation $(\%)=\underset{\times 100 / \text { mean }}{\text { standard deviation }}$

$$
\times 100 / \text { mean }
$$

To investigate the above hypothesis, Fig. 7 indicates coefficients of variation for the canopy spectral variables. For most variables, vegetation type was not significant as a source of the variations $(p>0.05)$, and the coefficients of variation were comparable between the canopies of the Acacia plantation plot and the evergreen forest. Vegetation type significantly influenced the coefficients of variation of magenta and $b^{*}$, but the coefficients of variation for the
Acacia canopy tended to be greater. These results did not support the hypothesis that the evergreen forest canopy indicates greater diversity of the tree community than does the Acacia canopy. Succession was likely to be ongoing in the Acacia plantation plots as reported by Kamo et al. (2002) who found 51 plant species in the Acacia plantation plot, in 1998, and 114 species in the evergreen forest. This transitional status of the Acacia plantation plot must have resulted in the apparent diversity of the canopy spectral profile by allowing other plant species to take root and to be remote sensing-captured through the gaps caused by self-thinning (Ashton et al. 2001). As the number of plant species is greater for the evergreen forest, the relatively more uniform spectral profile of the canopy should be attributed to the canopy leaves' spectral proximity among the upper storey species of Shorea species and Hopea ferrea (Kanzaki et al. 1995). These differences in the coefficient of variation also indicate that the plant community of the Acacia plantation plot was still changing towards the plant community structure of the evergreen forest. The difference in plant species composition (Kamo et al. 2002) could have significant effects on soil physicochemical and biological profiles. At the same time, soil physicochemical and biological conditions can affect the vegetative succession. However, this mutual relationship does not necessarily mean that 
Fig. 7 Coefficients of variation of the color components for canopies of the Acacia (open circle) and the evergreen forest (filled triangle) based on the remote sensing image acquired in April 2006

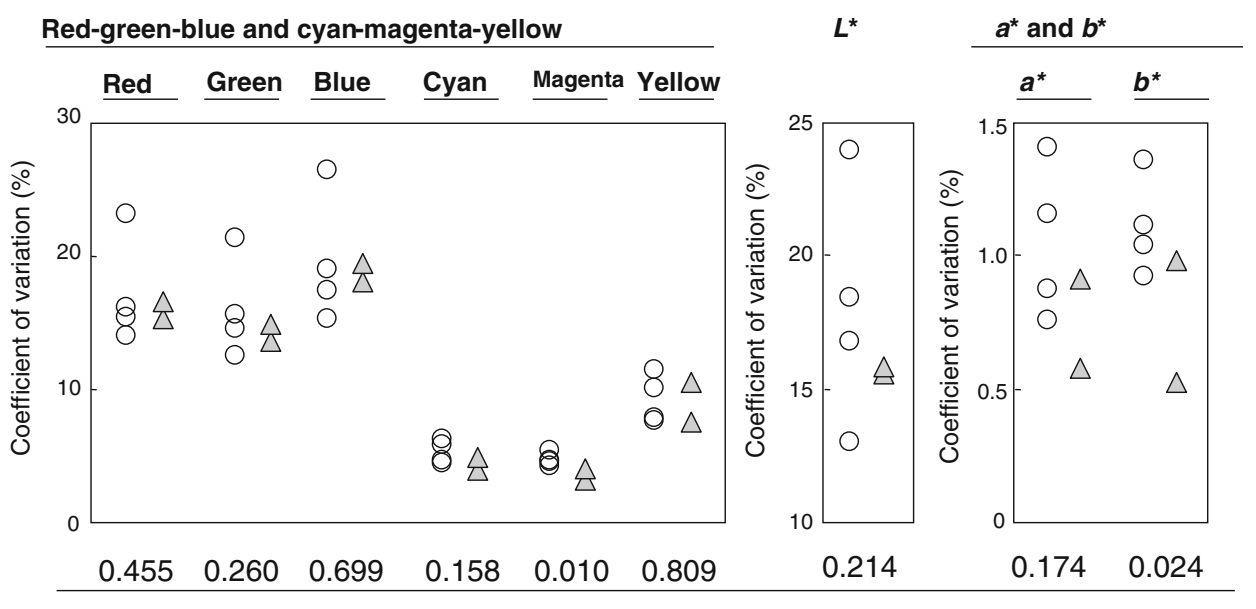

$p$ vaules provided by analyses of variance hypothesizing vegetation type as the source of variation restoration of a single ecosystem component is always followed by restoration of the others (Kardol and Wardle 2010). In this study, the restoration of soil microbial functions was found to be left behind that of vegetation and soil physicochemical conditions.

Consequences and perspective of the Acacia plantation in the region

Thus, the A. auriculiformis plantation soil and the ecosystem were very likely to be moving in succession towards full restoration. It will take at least several more years for the Acacia plantation plots to fully restore the original ecosystem to the point where there are no discernible differences from the evergreen forest. In humid tropics under similar climatic conditions, Yemefack et al. (2005) recognized incomplete soil fertility restoration in a comparable rehabilitation period of 15 years after shifting cultivation in Cameroon. In the southern Yucatan peninsula of Mexico, under similar climatic conditions, 40-60 years was estimated for restoration of total aboveground biomass after shifting cultivation, based on the most optimistic estimate (Chazdon 2003). In the current study site, the Acacia plantation resulted in relatively faster soil physicochemical and aboveground restoration, while the restoration of the soil microbial functions was slower. A similar delay in soil microbial restoration after establishment of vegetation has been previously reported (Tscherko et al. 2004). The Acacia plantation in Sakaerat was thought to have restored the soil physicochemical conditions that could further enhance the restoration of the plant community. On the other hand, the aforementioned results also suggest the lack of certain microbes that used to play significant roles in the evergreen forest soil. Hence, inoculation of effective microbes may be a way to further enhance the ecological restoration, especially by targeting specific microbial functions (Chanway 1997). The addition of particular inorganic nutrients (Table 1) may also be effective for enhancing the ecological restoration (Mataji et al. 2010; Kuramae et al. 2011). These actions are expected to further rehabilitate the belowground components for ecosystem restoration in the Acacia plantation plots so as to overcome the barrier (Ren et al. 2007) that the in-succession ecosystem seems to be encountering.

\section{Conclusion}

This study revealed a delay in the restoration of soil microbial functions related to the redox activities of the microbes compared with the restoration of the vegetation and soil physicochemical characteristics, which suggests a lack of soil microbes that used to play important roles in the original evergreen forest ecosystem. Therefore, once a tropical forest soil is severely degraded, some key microbes can be lost from the soil (Okot-Uma and Endeley 2004). Because microbes cannot move freely, it is difficult for them to be reintroduced to the reforestation site. The lack of such lost microbes may result in crippled ecological services (Bradshaw et al. 2007), which should be evaluated so that effective measures to restore the lost functions and ecological services can be taken, thereby enhancing the land rehabilitation processes following reforestation.

Acknowledgments All the staff members of the Sakaerat Environmental Research Station assisted this research activity. The authors gratefully acknowledge their relentless support. The authors also acknowledge Dr. Pitayakon Limtong and Ms. Karnmanee Jankhaw (Land Development Department, Thailand) for the detailed information on the uncultured bacterium from the Vetiveria rhizosphere. 


\section{References}

Anonymous (2011) The Eleventh National Economic and Social Development Plan (2012-2016). National Economic and Social Development Board of Thailand, Office of the Prime Minister, Bangkok, Thailand

Ashton M, Gunatilleke C, Singhakumara B, Gunatilleke I (2001) Restoration pathways for rain forest in southwest Sri Lanka: a review of concepts and models. For Ecol Manage 154(3):409-430

Badejo MA (1998) Agroecological restoration of savanna ecosystems. Ecol Eng 10(2):209-219

Baek S, Cui Y, Kim S, Cui C, Yin C, Lee S, Im W (2011) Tumebacillus ginsengisoli sp nov., isolated from soil of a ginseng field. Int J Syst Evol Microbiol 61(7):1715-1719

Bernhard-Reversat F (1999) The leaching of eucalyptus hybrids and Acacia auriculiformis leaf litter: Laboratory experiments on early decomposition and ecological implications in Congolese tree plantations. Appl Soil Ecol 12(3):251-261

Bradshaw CJA, Sodhi NS, Peh KS-H, Brook BW (2007) Global evidence that deforestation amplifies flood risk and severity in the developing world. Global Change Biol 13(11):2379-2395

Casida LE Jr, Klein DA, Santoro T (1964) Soil dehydrogenase activity. Soil Sci 98(6):371-376

Chanway CP (1997) Inoculation of tree roots with plant growth promoting soil bacteria: an emerging technology for reforestation. For Sci 43(1):99-112

Chazdon R (2003) Tropical forest recovery: Legacies of human impact and natural disturbances. Perspect Plant Ecol Evol Syst 6(1-2):51-71

Chen X, Su Y, He X, Wei Y, Wei W, Wu J (2012) Soil bacterial community composition and diversity respond to cultivation in Karst ecosystems. World J Microbiol Biotechnol 28(1):205-213

Doi R (2012) Simple luminosity normalization of greenness, yellowness and redness/greenness for comparison of leaf spectral profiles in multi-temporally acquired remote sensing images. J Biosci 37(4):723-730

Doi R, Ranamukhaarachchi SL (2007) Soil colour designation using Adobe Photoshop (TM) in estimating soil fertility restoration by Acacia auriculiformis plantation on degraded land. Curr Sci 92(11):1604-1609

Doi R, Ranamukhaarachchi SL (2009a) Community-level physiological profiling in monitoring rehabilitative effects of Acacia auriculiformis plantation on degraded land in Sakaerat. Thailand. Silva Fenn 43(5):739-754

Doi R, Ranamukhaarachchi SL (2009b) Correlations between soil microbial and physicochemical variations in a rice paddy: implications for assessing soil health. J Biosci 34(6):969-976

Doi R, Ranamukhaarachchi SL (2010) Discriminating between canopies of natural forest and Acacia plantation plots in a Google Earth image to evaluate forest land rehabilitation by Acacia species. Int J Agric Biol 12(6):921-925

Doi R, Sakurai K (2004) Principal components derived from soil physico-chemical data explained a land degradation gradient, and suggested the applicability of new indexes for estimation of soil productivity in the Sakaerat environmental research station, Thailand. Int J Sustain Dev World Ecol 11(3):298-311

Doi R, Wachrinrat C, Teejuntuk S, Sakurai K, Sahunalu P (2010) Semiquantitative color profiling of soils over a land degradation gradient in Sakaerat, Thailand. Environ Monit Assess 170(1-4):301-309

Eden MJ, Parry JT (1996) Land degradation in the tropics: environmental and policy issues. Global Development \& the Environment Series, Pinter, London

FAO/UNESCO 1979. Soil map of the world. IX, Southeast Asia. UNESCO, Paris
Fisher R, Hirsch P (2008) Poverty and agrarian-forest interactions in Thailand. Geogr Res 46(1):74-84

Fujii K, Hayakawa C, Van Hees PAW, Funakawa S, Kosaki T (2010) Biodegradation of low molecular weight organic compounds and their contribution to heterotrophic soil respiration in three Japanese forest soils. Plant Soil 334(1-2):475-489

Gamo M, Shoji T (1999) A method of profiling microbial communities based on a most-probable-number assay that uses BIOLOG plates and multiple sole carbon sources. Appl Environ Microbiol 65(10):4419-4424

Garland JL (1996) Patterns of potential C source utilization by rhizosphere communities. Soil Biol Biochem 28(2):223-230

Hackett CA, Griffiths BS (1997) Statistical analysis of the timecourse of Biolog substrate utilization. J Microbiol Methods 30(1):63-69

Hobbs RJ, Norton DA (1996) Towards a conceptual framework for restoration ecology. Restor Ecol 4(2):93-110

Jangid K, Williams MA, Franzluebbers AJ, Sanderlin JS, Reeves JH, Jenkins MB, Endale DM, Coleman DC, Whitman WB (2008) Relative impacts of land-use, management intensity and fertilization upon soil microbial community structure in agricultural systems. Soil Biol Biochem 40(11):2843-2853

Kaeoniam P, Khoorat P, Sunthornsan W, Issareeya M, Cherdchun C, Buachum W (1976) A study of illegal deforestation in the reserved forest area at the Sakaerat Environmental Research Station. Environmental and Ecological Research Department, Applied Scientific Research Corporation of Thailand, Bangkok

Kamo K, Vacharangkura T, Tiyanon S, Viriyabuncha C, Nimpila S, Doangsrisen B (2002) Plant species diversity in tropical planted forests and implication for restoration of forest ecosystems in Sakaerat, northeastern Thailand. JARQ 36(2):111-118

Kang BT (1993) Sustainable agroforestry systems for the tropics: concepts and examples. IITA Research Guide 26. IITA, Ibadan

Kanzaki M, Yoda K, Dhanmanonda K (1995) Mosaic structure and tree growth pattern in a monodomoinant tropical seasonal evergreen forest in Thailand. In: Box EO, Peet RK, Masuzawa T, Yamada I, Fujiwara K, Maycosk PF (eds) Vegetation science in forestry. Kluwer Publishers, Netherlands, pp 495-513

Kardol P, Wardle DA (2010) How understanding abovegroundbelowground linkages can assist restoration ecology. Trends Ecol Evol 25(11):670-679

Köppen W (1931) Grundriss der Klimakunde. Walter de Gruyter, Berlin

Krairapanond N, Atkinson A (1998) Watershed management in Thailand: concepts, problems and implementation. Regul Rivers Ress Manage. 14(6):485-498

Kuramae E, Gamper H, van Veen J, Kowalchuk G (2011) Soil and plant factors driving the com munity of soil-borne microorganisms across chronosequences of secondary succession of chalk grasslands with a neutral pH. FEMS Microbiol Ecol 77(2):285-294

Lin Y, Jangid K, Whitman WB, Coleman DC, Chiu C (2011) Change in bacterial community structure in response to disturbance of natural hardwood and secondary coniferous forest soils in central Taiwan. Microb Ecol 61(2):429-437

Lindstrom JE, Barry RP, Braddock JF (1998) Microbial community analysis: a kinetic approach to constructing potential C source utilization patterns. Soil Biol Biochem 30(2):231-239

Lugo AE (1997) The apparent paradox of reestablishing species richness on degraded lands with tree monocultures. For Ecol Manage 99(1-2):9-19

Mataji A, Moarefvand P, Kafaki SB, Kermanshahi MM (2010) Understory vegetation as environmental factors indicator in forest ecosystems. Int J Environ Sci Technol 7(4):629-638

Mboukou-Kimbatsa IMC, Bernhard-Reversat F, Loumeto JJ (1998) Change in soil macrofauna and vegetation when fast-growing 
trees are planted on savanna soils. For Ecol Manage 110(1-3): $1-12$

Mitchell RJ, Auld MHD, Le Duc MG, Marrs RH (2000) Ecosystem stability and resilience: a review of their relevance for the conservation management of lowland heaths. Perspect Plant Ecol Evol Syst 3(2):142-160

Okot-Uma RW, Endeley RM (2004) Biodiversity and gender for sustainable development: perspectives. Commonwealth Secretariat and SFI Publishing, London

Ponnusamy K, Choi JN, Kim J, Lee S-Y, Lee CH (2011) Microbial community and metabolomic comparison of irritable bowel syndrome faeces. J Med Microbiol 60(6):817-827

Preston-Mafham J, Boddy L, Randerson P (2002) Analysis of microbial community functional diversity using sole-carbonsource utilisation profiles-a critique. FEMS Microbiol Ecol 42(1):1-14

Ramsey PW, Rillig MC, Feris KP, Holben WE, Gannon JE (2006) Choice of methods for soil microbial community analysis: PLFA maximizes power compared to CLPP and PCR-based approaches. Pedobiologia 50(3):275-280

Ren H, Li ZA, Shen WJ, Yu ZY, Peng SL, Liao CH, Ding MM, Wu JG (2007) Changes in biodiversity and ecosystem function during the restoration of a tropical forest in south China. Sci China Ser C Life Sci 50(2):277-284

Sharp A, Nakagoshi N (2006) Rehabilitation of degraded forests in Thailand: policy and practice. Landsc Ecol Eng 2(2):139-146
Sprent JI, Parsons R (2000) Nitrogen fixation in legume and nonlegume trees. Field Crops Res 65(2-3):183-196

Strobel BW, Bernhoft I, Borggaard OK (1999) Low-molecularweight aliphatic carboxylic acids in soil solutions under different vegetations determined by capillary zone electrophoresis. Plant Soil 212(2):115-121

Trevors J (1996) DNA in soil: adsorption, genetic transformation, molecular evolution and genetic microchip. Antonie Leeuwenhoek 70(1):1-10

Tscherko D, Hammesfahr U, Marx MC, Kandeler E (2004) Shifts in rhizosphere microbial communities and enzyme activity of Poa alpina across an alpine chronosequence. Soil Biol Biochem 36(10):1685-1698

Vonmersi W, Schinner F (1991) An improved and accurate method for determining the dehydrogenase-activity of soils with iodonitrotetrazolium chloride. Biol Fertility Soils 11(3):216-220

Werdin-Pfisterer NR, Kielland K, Boone RD (2009) Soil amino acid composition across a boreal forest successional sequence. Soil Biol Biochem 41(6):1210-1220

Yemefack M, Rossiter D, Njomgang R (2005) Multi-scale characterization of soil variability within an agricultural landscape mosaic system in southern Cameroon. Geoderma 125(1-2):117-143

Zar JH (1999) Biostatistical analysis. Prentice-Hall, New Jersey 